\title{
A DISAGGREGATED ANALYSIS OF MONETARY POLICY EFFECTS ON THE AGRICULTURAL SECTOR IN NIGERIA
}

\author{
Jonathan E. Ogbuabor ${ }^{1}$, Onyinye I. Anthony-Orji ${ }^{2}$, Charles O. Manasseh ${ }^{3}$, Anthony Orji ${ }^{4}$ \\ ${ }^{1,2,4}$ Department of Economics, University of Nigeria, Nsukka, Nigeria \\ ${ }^{3}$ Department of Banking and Finance, University of Nigeria, Enugu, Nigeria
}

\author{
jonathan.ogbuabor@unn.edu.ng \\ onyinye.anthony-orji@unn.edu.ng \\ charssille@gmail.com \\ anthony.orji@unn.edu.ng
}

\begin{abstract}
This study provides a disaggregated analysis of the effects of monetary policy shocks on the agricultural sector in Nigeria from $1981 Q 1$ to 2016Q4. The study utilized the generalized impulse responses and the normalized generalized forecast error variance decompositions from an underlying VAR model, which are order-invariant. The four monetary policy variables used in the study are interbank call rate, monetary policy rate, broad money supply and exchange rate; while the four agricultural sub-sectors investigated are crop production, forestry, fishing and livestock. The study also controlled for the general price level and other economic activities in the overall economy. The findings indicate that the aggregate agricultural sector and its various sub-sectors consistently responded negatively to unanticipated monetary tightening in most of the forecast horizon; while the immediate impact of monetary policy shocks is transmitted to the agricultural sector through the interest rate and money demand (credit) channels. The findings further indicate that apart from these two channels, the roles of monetary policy rate and exchange rate are non-negligible in the long-run. The role of money supply channel in spreading monetary policy shocks to the agricultural sector remained muted all through. The study concludes that the monetary authority should evolve interest rate, credit, and exchange rate policies that will promote the development of the agricultural sector in Nigeria.
\end{abstract}

Keywords: Disaggregated, Monetary Policy; Agricultural Sector; VAR Model; Nigeria (JEL code: E52; N50; C22; N57)

\section{INTRODUCTION}

Monetary policy is one of the macroeconomic management tools used to influence outcomes in the real sectors of an economy to their desired direction. It is expected to influence the real sectors of an economy through movements in interest rates which would alter the cost of capital and investment in these sectors. In fact, the extant literature indicates that monetary policy influences the economy through an array of channels, such as interest rates, credit and/or bank lending, asset prices through exchange rates, equity and housing prices channels (Mishkin, 2007; CBN, 2014). However, the main aims of monetary policy are the promotion of price stability, sustainable output and employment.
Recent investigations into the effect of monetary policy on the economy have generally focused on the sectoral effects of monetary policy since different sectors of the economy respond differently to monetary policy shocks (Moussir and Chatri, 2017). Such investigations have important policy implications for macroeconomic management since monetary authorities can then consider the effects of their actions on the various sectors of the economy. For example, the tightening of monetary policy might be considered benign from the general perspective, whereas it can also be viewed as malignant for certain sectors of the economy. Thus, monetary policy is said to have strong distributional effects on the economy, and empirical evidence on how the various sectors react to monetary policy shocks is essential about how to stimulate growth. 
Current empirical studies on the sectoral effects of monetary policy shocks in developing countries generally indicate that tight monetary policy negatively affects the agricultural sector, which is one of the key components of the real economy in Nigeria (CBN, 2014; Moussir and Chatri, 2017). Indeed, over the years, the agricultural sector has made great contributions to domestic production, employment and foreign exchange earnings in Nigeria (Oluwaseyi (2017). However, a trend analysis of its contributions to Nigeria's gross domestic product (GDP) has revealed a substantial variation and long-term decline since the early 1960 s. Specifically, its contribution to GDP declined from $60 \%$ in the early 1960 's to $23.11 \%$ in 2015 . Its contribution to GDP further declined to $20.48 \%$ in 2016Q1. In addition, the real growth rate of the sector declined from $6.70 \%$ in 2012 to $3.72 \%$ in 2015 . Its growth rate declined to $3.09 \%$ as at 2016Q1. This unsatisfactory situation has been largely attributed to unstable and often inappropriate economic policies, the relative neglect of the sector and the negative impact of oil boom (Orji, A., Ogbuabor, Anthony-Orji, and Alisigwe, 2020, Ogbuabor and Nwosu, 2017; National Bureau of Statistics, 2016). Thus, economic policies in Nigeria, such as the monetary policies of the Central Bank of Nigeria (CBN), cannot be said to be successful if they do not impact positively on the real sectors of the economy, especially the agricultural sector that employs and feeds the larger chunk of the country's population. The goal of this study is to provide a disaggregated analysis of the effects of monetary policy shocks on the agricultural sector in Nigeria ${ }^{1}$. Agriculture is as old as man himself as it was the first occupation of mankind. Even with the evolvement of modern civilization, it still remains an essential part of the growth and development of any extant economy (Anthony-Orji, Orji, Ogbuabor \& Ezealigo, 2020; Orji, Ogbuabor, Okeke \& Anthony-Orji, 2019; Orji, Ogbuabor, and Umesiobi, 2014).

This study is relevant for several reasons. One, existing studies have generally neglected the disaggregated nature of the agricultural sector in Nigeria. To address this gap, this study specifically evaluated the effects of monetary policy on the four agricultural sub-sectors in Nigeria, namely: crop production, livestock, forestry and fishing. Two, an important methodological flaw in studies that have examined the sectoral effects of monetary policy in Nigeria, such as CBN (2014) and Nwosa and Saibu (2012), is the use of vector autoregressive (VAR) framework that is not order-invariant. To address this gap, this study used the generalized impulse response and the generalized forecast error variance decomposition framework advanced by Koop, Pesaran and Potter (1996) and Pesaran and Shin (1998), which was later extended by Diebold and Yilmaz (2014). Overall, this study will assist in strengthening the formulation and implementation of monetary policy in Nigeria, particularly as it affects the agricultural sector.

1 For detailed historical account on the evolution of monetary policy in Nigeria, we refer the reader to CBN (2014). Similarly, for the historical evolution of the agricultural sector in Nigeria, we refer the reader to Oluwaseyi (2017).

\section{AN OVERVIEW OF THE EMPIRICAL LITERATURE}

In the last two decades, several studies have been conducted to ascertain the sectoral effects of monetary policy, especially in the highly industrialized economies. One of the pioneer seminal papers in this regard is Bernanke and Gertler (1995), which used a vector autoregressive (VAR) model to document the responses of GDP and its components in the U.S. to monetary policy shocks. They find that during the period January 1965 to December 1993, the different components of final expenditures responded differently to monetary policy shocks. Following this study, a plethora of other studies also focused on the U.S. economy. Raddatz and Rigobon (2003) used quarterly data for the U.S. over the period 1955:1 2002:3 to examine the sectoral effects of monetary policy. They extended the Bernanke and Gertler (1995) methodology by advancing an identification strategy that allows the study of both the sectoral effects of monetary policy and the role that monetary policy plays in the transmission of sectoral shocks. The results also indicate significant differences in the sectoral responses to monetary policy. Jansen, Kishan and Vacaflores (2013) studied the impact of monetary policy on net sales of publicly traded firms in various sectors of the U.S. economy and find that monetary policy has a heterogeneous effect on firms in different industries. The study observed the strongest effect on firms in retail and wholesaling, while balance sheet characteristics, particularly size, influence the impact of policy.

At this point, it is easily seen that monetary policy influences different sectors of the economy in different ways. In what follows, we explore empirical studies from other economies across the globe in order to cross check the robustness of this fact. Otero (2017) investigated the impact of monetary policy on the industrial sectors in five Latin American countries using inflation targeting, namely: Brazil, Chile, Colombia, Mexico and Peru. Among others, the results indicate that the sub-sectors producing capital goods and durable consumer goods are more sensitive to monetary policy shocks. In the UK, Ganley and Salmon (1997) examined the disaggregated impacts of monetary policy on 24 industrial sub-sectors in order to establish the speed and magnitude of the reactions of firms in those sub-sectors to an unexpected monetary policy tightening. The results indicate that the sensitivity of output to changes in monetary conditions differs noticeably across industries. This is consistent with Darby and Phillips (2007), which established from impulse responses of VARs for disaggregated UK and Scottish data that some industrial sub-sectors are more interest sensitive compared to others.

Studies in Australia also obtained similar results with the ones above, which on the whole, supports the hypothesis of differential sectoral impacts of monetary policy. Lawson and Rees (2008) examined the effects of unexpected monetary policy shocks on the Australian expenditure and production components of GDP from 1983 to 2007 using a structural vector autoregression (SVAR). The results indicate that 
dwelling investment, and machinery and equipment investment are the most interest-sensitive expenditure components of activity, while construction and retail trade are the most interest-sensitive production components of activity. In an earlier study of the sectoral output impacts of monetary policy in Australia using a structural vector autoregression (SVAR) model, Crawford (2007) also found that monetary policy shocks have uneven impacts across different sectors, with the construction and manufacturing sectors showing the most sizeable and rapid responses to monetary tightening, while the mining sector is not interest rate-sensitive.

Singh and Rao (2014) and Sengupta (2014) studied the sectoral effects of monetary policy in India. Singh and Rao (2014) examined the responses of both aggregate and sectoral output to monetary policy shock using reduced form vector auto regression (VAR) model and find that the impact of a monetary policy shock at the sectoral level is heterogeneous, with some sectors like mining and quarrying, manufacturing, construction and trade, hotel, transport and communications being more responsive to monetary tightening, suggesting the need for sector-specific monetary policy in India. Sengupta (2014) also used VAR model to find that the impact of a monetary policy shock at the sectoral level is heterogeneous and that sectors like manufacturing, mining and quarrying, construction and trade are the fastest to respond, with manufacturing being the most responsive. Just as before, Sengupta (2014) concluded that the heterogeneous sectoral responses suggest the need for a more sector-specific monetary policy in India.

In Europe, Pellényi (2012) used a structural factor model to find considerable heterogeneity in the sectoral responses to monetary policy shocks in Hungary, with sectors more dependent on external finance showing greater output responses, while healthier corporate balance sheets showed weaker price responses. In South Asia, Alam and Waheed (2006) studied the responses of both aggregate and sectoral production to monetary policy shocks using a standard VAR framework and find that some sectors are more sensitive to monetary tightening. Specifically, the results indicate that manufacturing, wholesale and retail trade, and finance and insurance sectors declined more in response to interest rate shocks, while agriculture, mining and quarrying, construction, and ownership of dwellings are less sensitive to interest rate changes. Llaudes (2007) examined the differential effects of monetary tightening on the tradable and non-tradable sectors in the OECD, and find that the behavior of these two sectors varies within the countries, with the tradable sector showing greater degree of responsiveness to monetary policy shocks than the non-tradable sector. This suggests that industrial structure may be an important component for the analysis of monetary policy.

At this point, it is obvious that empirical studies have established a fact, that monetary tightening generates differential sectoral effects. Some empirical studies focusing on African economies are also consistent with this fact. Nampewo, Munyambonera and Lwanga (2013) examined the sectoral effects of monetary policy in Uganda for the period
1999 to 2011 using a recursive VAR and find that agriculture, manufacturing and service sectors respond differently to monetary tightening, with a positive shock in exchange rates resulting in the growth of agriculture and service sectors as well as decline in the manufacturing sector. This suggests the need for a stable exchange rate regime, which favors all the productive sectors of the economy. Moussir and Chatri (2017) also finds significant differences in the reactions of Moroccan sectors to monetary policy shocks, with the extraction industry, manufacturing, construction, hotels \& restaurants, the financial and insurance activities being more sensitive to monetary policy shocks, while agriculture and fishing sectors appear to be insensitive to monetary policy innovations. The results further indicate that monetary policy tightening leads to a decrease of the overall GDP and price level.

In Nigeria, Nwosa and Saibu (2012) examined the transmission channels of monetary policy shocks on sectoral output growth over the period 1986Q1 - 2009Q4 using Granger Causality and unrestricted VAR model. The results indicate that interest rate channel is most effective in transmitting monetary policy to agriculture and manufacturing sectors, while exchange rate channel is most effective for transmitting monetary policy to building/construction, mining, service and wholesale/retail sectors. These results generally indicate that interest rate and exchange rate policies are important monetary policy measures for stimulating sectoral output growth in Nigeria. CBN (2014) criticized this study on two main grounds. The first is that the period covered by the study does not reflect the market orientation period of monetary policy in Nigeria. The second is that the unrestricted VAR model used in the study is sensitive to the ordering of the variables. To address these gaps, CBN (2014) used structural VAR framework and quarterly data from 1993Q1 to 2012Q4 to examine monetary policy effects on the disaggregated components of the real sector in Nigeria. The results indicate that sectoral output responded heterogeneously following contractionary monetary policy shocks, with some immediately responding negatively (services and wholesale/retail sectors), while others displayed lagged negative responses (manufacturing, building and construction, and agriculture). This is consistent with the theoretical expectation that output in each sector is expected to decline following monetary tightening. It is also consistent with the established fact that monetary policy shocks generate differential sectoral impacts. The findings of CBN (2014) further indicate that contrary to Nwosa and Saibu (2012), money supply is one of the main variables that explain the variation in sectoral output, while exchange rate does not significantly explain sectoral output changes.

Three important observations are in order at this point. The first is that the effects of monetary policy on the agricultural sector in Nigeria are yet to be investigated at a disaggregated level. It is the goal of this study to fill this gap in the literature by investigating the effects of monetary policy on the four agricultural sub-sectors in Nigeria. The second important issue here is that CBN (2014) carried out level form estimations of the underlying VAR models without 
recourse to any kind of cointegration test. Obviously, the estimated models may have been misspecified when the variables are subjected to cointegration test. It is the goal of this study to cure this important methodological flaw by performing a system cointegration test. The third issue also bothers on the methodology, that is, the use of VAR system that is sensitive to the ordering of the variables. To address this issue, CBN (2014) employed structural VAR framework, and utilized the non-recursive method of imposing restrictions in structural VARs for the aggregate and sectoral output components using economic theory as the basic foundation. However, it has since been established in the literature that VAR models are atheoretical because they are not based on any economic theory; they take the view that let the data talk about themselves (Cooley and Leroy, 1985). Indeed, the modeling strategy suggested by Sims (1980) is to estimate an ('unrestricted') VAR model of a pre-specified order in variables of interest and to make use of impulse response functions to investigate the dynamic response of the system to shocks without having to rely on 'incredible' identifying restrictions, or potentially controversial restrictions from economic theory. The critical issue here is that imposing a causal ordering on the VAR based on economic theory defeats the object of this approach, and in general, no such restrictions are available or acceptable. In the absence of such restrictions, the estimated model gives few meaningful insights into the economic system that it represents. Obviously, the attempt by CBN (2014) to address the methodological gap of estimating an order-invariant impulse response functions or forecast error variance decompositions leaves more questions than answers. It is the goal of this study to address this methodological gap using the order-invariant generalized impulse responses and generalized forecast error variance decompositions following Koop, Pesaran and Porter (1996).

\section{MATERIALSANDMETHODS}

The full sample data for this study spans from 1981Q1 to 2016Q4, while the sub-sample period is from 1994Q1 to 2016Q4. The full sample period is based on available data, while the sub-sample period is used to capture the era of indirect monetary policy regime in Nigeria, following CBN (2014). The monetary policy variables used in this study include: broad money supply (M2), measured in billions of naira (MSS); nominal naira to U.S. dollar exchange rate (EXR); monetary policy rate (MPR), measured in percent (\%); and interbank call rate (IBR), measured in percent (\%). These policy variables are regularly used by the $\mathrm{CBN}$ as stabilization tools. In particular, the MPR serves as the CBN anchor rate as well as the point of reference rate for overnight interest rates in the money market. The choice of these policy variables is to ensure the comparability of our results with the extant literature such as CBN (2014) and Nwosa and Saibu (2012). The non-policy variables in this study include: consumer price index (CPI), measured in percent (\%), which captures the general price level; agricultural sector real GDP component (AGR), measured in billions of naira, which accounts for economic activities in the agricultural sector; and the four subsectoral real GDP components under the agricultural sector, which are crop production (CPR), livestock (LVS), forestry (FRS) and fishing (FSH), all measured in billions of naira. The aim is to determine how monetary policy influences the agricultural sector as a whole and at the disaggregated (or sub-sectoral) level. The entire data were collected from the CBN Statistical database and logged before estimation.

The descriptive statistics of the variables indicate that the highest agricultural output of 12.586 trillion naira was recorded in 2009Q4, while the average value is 5 trillion naira. The statistics also indicate that among the four agricultural sub-sectors, crop production has the highest average output of 4.328 trillion naira, while forestry has the least average output of 77.84 billion naira. The statistics further show that monetary policy rate and interbank call rate witnessed the least level of variability among all the variables. We refer the reader to Table 2 in the Appendix for more details of the descriptive statistics of the variables before they were logged for estimation.

This study seeks to provide a disaggregated analysis of the effect of monetary policy shocks on the agricultural sector in Nigeria. To do this, we specify a multivariate VAR model of the form:

$$
Z_{t}=\alpha_{z}+\sum_{j=1}^{p} \Phi_{j} Z_{t-j}+\varepsilon_{t},
$$

where: $Z_{t}$ is a vector of both monetary policy and nonmonetary policy variables; $\alpha$ is a vector of intercepts; $\phi_{j}$ is the coefficient matrix; $\boldsymbol{p}$ is the lag order; and the residuals $\varepsilon_{i t} \sim \operatorname{iid}\left(0, \sum_{\varepsilon, i i}\right)$ Schwarz Information Criterion selected an optimal VAR lag order of one for this study (see Table 5 in the Appendix). For the aggregate agricultural output (AGR), this study estimated a six-variable VAR, which includes the four monetary policy variables and CPI. A separate seven-variable VAR was estimated for each agricultural sub-sector in order to account for the effect of monetary policy shocks on the various sub-sectors. In addition to the sub-sectoral outputs, the sub-sectoral VARs include the four monetary policy variables, $\mathrm{CPI}$, and a second output variable, $Y_{j}$, for the $j$ th agricultural sub-sector. The output variable, $Y_{j}$, is constructed as the net aggregate output $\left(Y_{t}-Y_{j t}\right)$ that excludes that particular subsector when estimating the individual sectoral VAR, in line with CBN (2014). Here, $Y_{t}$ is the aggregate agricultural output at time $t$, and $Y_{j t}$ is the individual sub-sectoral output. All the models in this study proved to be stable (for example, see the stability test result in Table 6 of the Appendix).

The approach adopted in this study requires that after estimating the underlying VAR model, the generalized impulse responses (GIRs) and the generalized forecast error variance decompositions (GFEVDs) are then generated. The GIRs are used to trace the dynamic responses of the aggregate agricultural sector and its various sub-sectors within the VAR system to monetary tightening. For a detailed theoretical background on the GIRs, we refer the reader to Pesaran and Shin (1998). The GFEVDs are used to trace the variation in the aggregate agricultural sector and its various sub-sectors 
within the VAR system that is accounted for by own shocks as well as shocks from the monetary policy variables in the system. This is with a view to establishing the main channels through which monetary policy shocks are transmitted to the agricultural sector and its various sub-sectors. Hence, following Koop, Pesaran and Potter (1996) and Pesaran and Shin (1998), this study adopts the order-invariant GFEVDs defined as:

$$
\operatorname{GFEVD}\left(Z_{i t} ; \varepsilon_{j t}, \boldsymbol{H}\right)=\boldsymbol{d}_{i j}^{g H}=\frac{\sigma_{\varepsilon, j}^{-1} \sum_{h=0}^{H-1}\left(e_{i}^{\prime} \Theta_{h} \Sigma_{\varepsilon} e_{j}\right)^{2}}{\sum_{h=0}^{H-1}\left(e_{i}^{\prime} \theta_{h} \Sigma_{\varepsilon} \theta_{h}^{\prime} e_{i}\right)}
$$

where $i, j=1, \ldots, N ; N$ is the number of variables in the system; $H=1,2, \ldots$ is the forecast horizon; $\mathrm{e}_{\mathrm{i}}\left(\mathrm{e}_{\mathrm{j}}\right)$ is $N \times 1$ selection vector whose i-th element ( $j$-th element) is unity with zeros elsewhere; $\Theta_{h}$ is the coefficient matrix multiplying the h-lagged shock vector in the infinite movingaverage representation of the non-orthogonalized VAR; $\sum_{\varepsilon}$ is the covariance matrix of the shock vector in the nonorthogonalized VAR; and $\sigma_{\varepsilon, \mathrm{jj}}$ is the $j$-th diagonal element of $\sum_{\varepsilon}$ (i.e. the standard deviation of $\mathrm{e}_{j}$ ). It must be stressed that the choice of GFEVDs for this study rather than the orthogonalized forecast error variance decompositions (OFEVDs) of Nwosa and Saibu (2012) and CBN (2014) is particularly based on the fact that the OFEVDs depend on the reordering of the variables in the system such that once the order of variables in the VAR is reshuffled, a different outcome results. Studies like Diebold and Yilmaz (2014), Ogbuabor et al. (2016), and Ogbuabor et al. (2018) have successfully used the GFEVDs in the study of international transmission of macroeconomic shocks and connectedness.

Diebold and Yilmaz (2014) explain that shocks are rarely orthogonal in the GFEVD environment so that sums of forecast error variance contributions are not necessarily unity, that is, row sums of the GFEVD matrix, , are not necessarily unity. This renders the interpretation of the GFEVDs complicated. Thus, to restore a percentage interpretation of the GFEVDs, this study follows Diebold and Yilmaz (2014) to define the normalized GFEVDs (NGFEVDs) given by:

$$
\widetilde{D}^{g H}=\left[\tilde{d}_{i j}^{g}\right] \quad \text { where } \tilde{d}_{i j}^{g H}=\frac{d_{i j}^{g}}{\sum_{j=1}^{N} d_{i j}^{g}} \quad d_{i j}^{g H}=\boldsymbol{G F E V D}\left(\boldsymbol{Z}_{i t} ; \varepsilon_{j t}, \boldsymbol{H}\right)
$$

By construction, $\sum_{j=1}^{N} \tilde{d}_{i j}^{g H}=1$, so that the total sum of the generalized forecast error variance share of each variable in the VAR system is normalized to $100 \%$ across all horizons.

\section{RESULTS AND DISCUSSION}

This empirical analysis began by examining the time series properties of the data. Both the Augmented Dickey-Fuller (ADF) and Phillips-Perron unit root tests showed that majority of the series are I(1) (see Table 3 in the Appendix). The test for long-run or equilibrium relationship using the Johansen System Cointegration test also showed the existence of at least four cointegrating equations (see Table 4 in the Appendix).
Therefore, the underlying model was estimated in its vector error correction form, and both the GIRs and the NGFEVDs were computed for horizons, , in order to properly capture the long run results. For the full sample (i.e. 1981Q1 to 2016Q4), the NGFEVDs of aggregate agricultural output (AGR), consumer price index (CPI) and the four agricultural sub-sectors (i.e. crop production, forestry, fishing, and livestock) are reported in Table 1. The corresponding sub-sample estimation results (i.e. 1994Q1 to 2016Q4) are reported in Table 7 (see the Appendix). The reports are shown from horizon 1 (i.e. the short-run) to horizon 24 (i.e. the long-run). Notice that the sum of each row in all the reports is $100 \%$, in line with equation (3). In what follows, we provide a detailed discussion of these results with a view to exposing how monetary policy shocks influence agriculture and its sub-sectors in Nigeria.

To begin, let us focus on the aggregate agricultural output. Figure 1 reports the generalized impulse response, which is a means of tracing the dynamic responses of endogenous variables within the VAR system to monetary policy shocks. The aggregate agricultural output responded immediately and negatively to innovation in money supply and monetary policy rate as theoretically expected. The highest negative response was attained after a lag of 2 and 6 quarters, respectively. In both cases, the sector persistently responded negatively all through. The response to interbank call rate declined after 2 quarters, became negative after 4 quarters and persistently remained negative afterwards. The lag pattern in the response of aggregate agricultural output to a restrictive monetary policy in this study may be explained by the fact that Nigerian agriculture is dominated by small scale farmers who depend largely on crude farming methods, while the lack of capital intensity in the sector may also offer an alternative explanation. This is consistent with CBN (2014). Overall, the aggregate agricultural sector generally responded negatively to unanticipated monetary policy shock in most of the forecast horizon, which is consistent with economic theory, as outputs in the real sectors of the economy are expected to decline following monetary tightening.

The variance decomposition of agricultural output in Table 1 indicates that in the short-run (i.e. horizon 1), $94.7 \%$ of the variation in agricultural output (AGR) is explained by its own innovation while interbank call rate (IBR) accounts for $4.8 \%$. The role of shocks from other monetary policy variables is considered negligible. Hence, we infer that interbank call rate is the main channel of transmitting monetary policy to the agricultural sector in the short-run. However, in the long-run (i.e. horizon 24), the roles of monetary policy rate (MPR) and exchange rate (EXR) become non-negligible since they contribute $11.2 \%$ and $8.45 \%$ to the total variation in agricultural output, respectively. Overall, therefore, we find that interbank call rate, monetary policy rate and exchange rate are the key channels through which monetary policy shocks are transmitted to the agricultural sector in Nigeria. These findings are qualitatively robust to the sub-sample estimation results in Table 7 (see the Appendix). The only difference is that in the sub-sample, the role of exchange rate remained unimportant throughout. These findings are consistent with Nwosa and 
Saibu (2012), which also established that interest rate is the main avenue of transmitting monetary policy shocks to the agricultural sector in Nigeria. Our findings are however contrary to CBN (2014), which found that monetary policy affects the agricultural sector through the money supply channel. The inconsistency in the findings of CBN (2014) may be due to the reordering of the variables in their structural VAR model. As explained in Section 3 of this paper, our VAR system is invariant to the reordering of the variables.
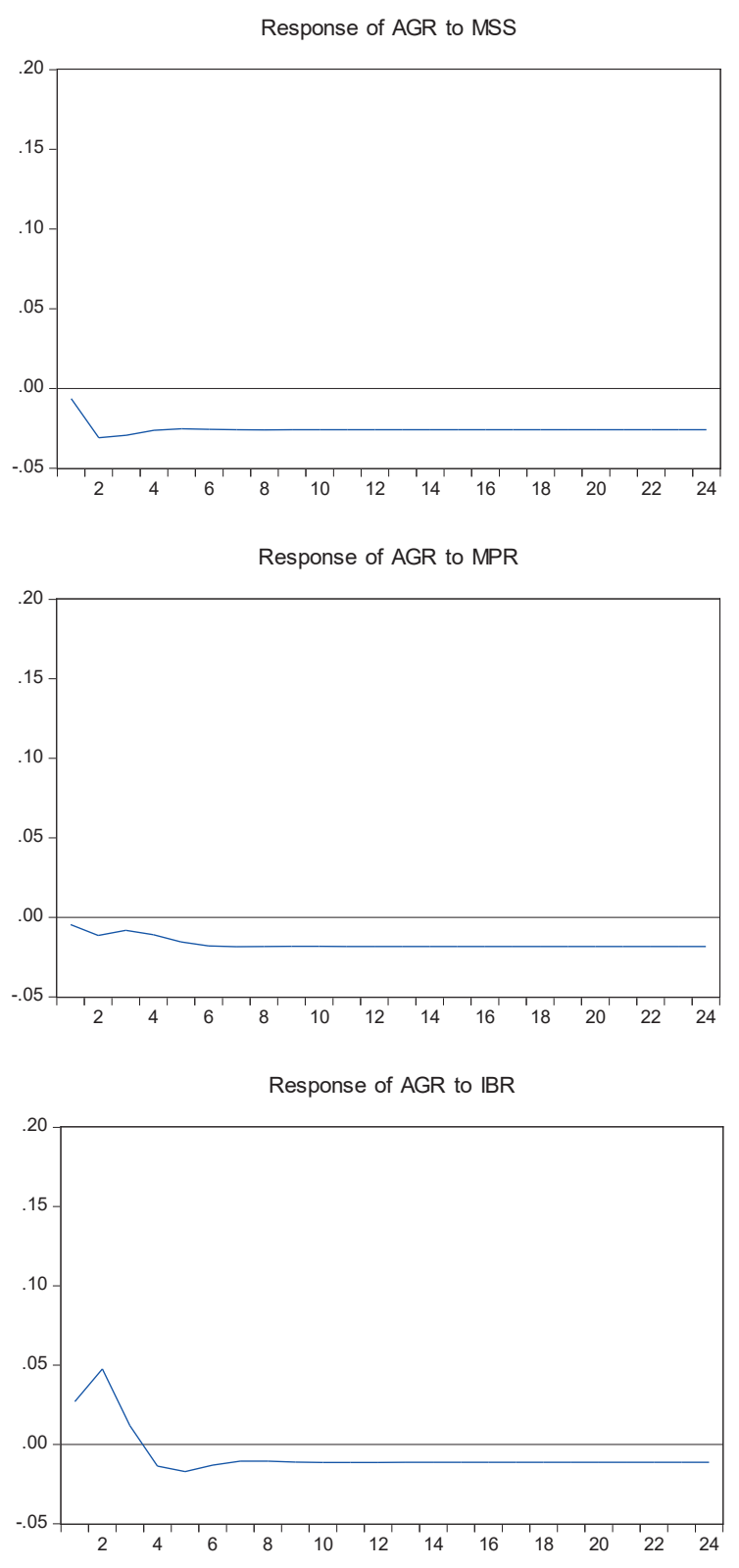

Figure 1: Generalized Impulse Response of Agricultural Sector to Monetary Policy Tightening:

Note: This figure reports for the full sample. To conserve space, we do not report the graphs for the sub-sample since they follow the same patterns. The response to innovations in exchange rate remained muted in all cases.
Figure 2: Generalized Impulse Response of Crop Production Subsector to Monetary Policy Tightening:

Response of CPR to MSS
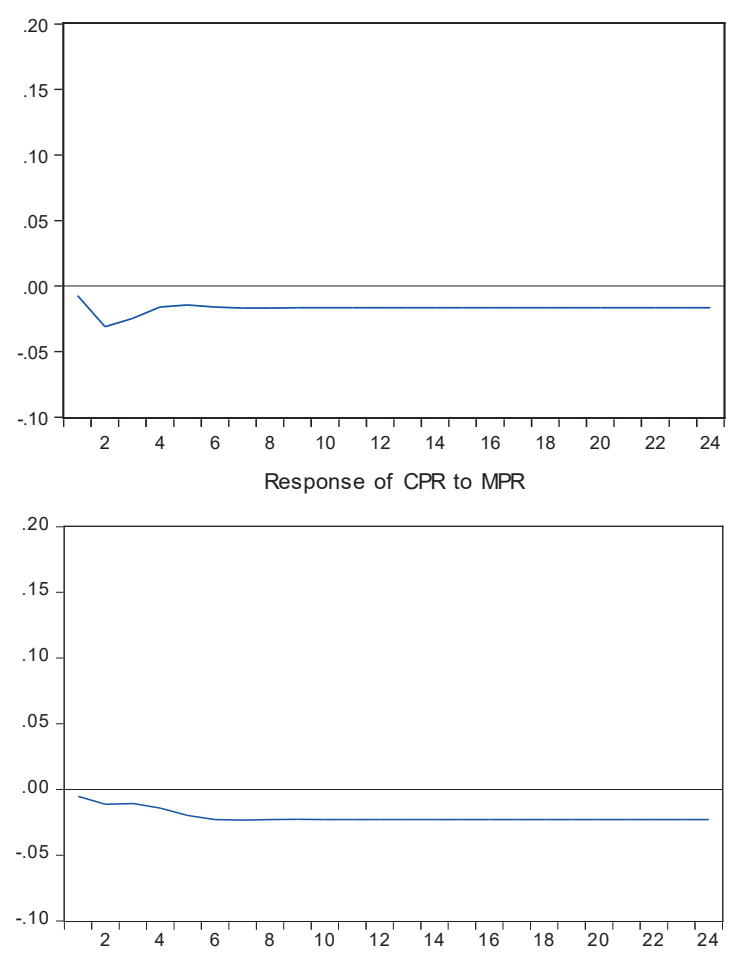

Response of CPR to IBR

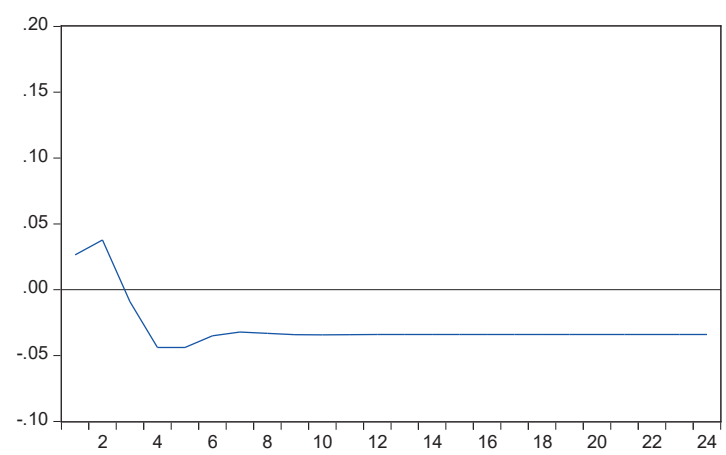

Note: This figure reports for the full sample. To conserve space, we do not report the graphs for the sub-sample, and for forestry, fishing and livestock sub-sectors, since they follow the same patterns. The response to innovations in exchange rate remained muted in all cases.

Table 1: Full Sample NGFEVD (1981Q1 - 2016Q4)

Agricultural Output

\begin{tabular}{cccccccc}
\hline Horizon & agr & ibr & mss & mpr & exr & cpi & Total \\
\hline 1 & 94.7486 & 4.7702 & 0.0108 & 0.3169 & 0.1532 & 0.0004 & 100 \\
4 & 89.6924 & 8.1075 & 0.0058 & 0.6838 & 1.2196 & 0.2909 & 100 \\
8 & 82.0092 & 10.1113 & 0.0058 & 3.4825 & 3.4150 & 0.9761 & 100 \\
12 & 75.3542 & 10.8340 & 0.0114 & 6.7373 & 5.5762 & 1.4867 & 100 \\
16 & 71.0002 & 10.9575 & 0.0194 & 9.1732 & 7.1317 & 1.7180 & 100 \\
20 & 68.7187 & 10.8693 & 0.0273 & 10.5825 & 8.0265 & 1.7757 & 100 \\
24 & 67.7461 & 10.7560 & 0.0341 & 11.2439 & 8.4505 & 1.7695 & 100 \\
\hline
\end{tabular}




\section{Consumer Price Index}

\begin{tabular}{cccccccc}
\hline Horizon & agr & ibr & mss & mpr & exr & cpi & Total \\
\hline 1 & 0.0004 & 0.0594 & 2.2447 & 1.2066 & 0.2235 & 96.2653 & 100 \\
4 & 0.0490 & 0.0226 & 2.7930 & 1.3660 & 0.1074 & 95.6621 & 100 \\
8 & 0.2027 & 0.0281 & 3.5348 & 1.7032 & 0.1385 & 94.3928 & 100 \\
12 & 0.2748 & 0.0632 & 4.2548 & 2.0650 & 0.2440 & 93.0984 & 100 \\
16 & 0.2700 & 0.0897 & 4.9457 & 2.3529 & 0.3195 & 92.0221 & 100 \\
20 & 0.2838 & 0.0968 & 5.6034 & 2.5195 & 0.3418 & 91.1547 & 100 \\
24 & 0.3690 & 0.0959 & 6.2221 & 2.5757 & 0.3385 & 90.3988 & 100 \\
\hline
\end{tabular}

\begin{tabular}{ccccccccc}
\multicolumn{8}{c}{ Crop Production } \\
\hline Horizon & $\mathrm{cpr}$ & $\mathrm{ibr}$ & $\mathrm{mss}$ & $\mathrm{mpr}$ & $\mathrm{exr}$ & $\mathrm{cpi}$ & $\mathrm{Y}_{\mathrm{j}}$ & Total \\
\hline 1 & 59.9417 & 2.8073 & 0.0137 & 0.2377 & 0.0811 & 0.0026 & 36.9159 & 100 \\
4 & 56.0044 & 4.9510 & 0.0132 & 0.4610 & 0.6539 & 0.1354 & 37.7812 & 100 \\
8 & 51.9284 & 6.3388 & 0.0442 & 2.4037 & 1.8858 & 0.5012 & 36.8979 & 100 \\
12 & 48.7583 & 7.0212 & 0.0752 & 4.8194 & 3.2166 & 0.7903 & 35.3190 & 100 \\
16 & 46.6428 & 7.2931 & 0.1004 & 6.7739 & 4.2811 & 0.9273 & 33.9815 & 100 \\
20 & 45.4720 & 7.3488 & 0.1189 & 7.9971 & 4.9613 & 0.9630 & 33.1389 & 100 \\
24 & 44.9354 & 7.3224 & 0.1318 & 8.6186 & 5.3206 & 0.9600 & 32.7112 & 100 \\
\hline
\end{tabular}

Forestry

\begin{tabular}{ccccccccc}
\hline \multicolumn{1}{c}{ Forestry } \\
\hline Horizon & frs & ibr & mss & mpr & exr & cpi & $\mathrm{Y}_{\mathrm{j}}$ & Total \\
\hline 1 & 59.0622 & 2.7616 & 0.3967 & 0.3909 & 0.0013 & 0.0086 & 37.3785 & 100 \\
4 & 54.0792 & 3.7271 & 0.1899 & 0.4779 & 0.1799 & 0.6334 & 40.7124 & 100 \\
8 & 49.3537 & 5.0064 & 0.1451 & 2.5143 & 0.9734 & 1.7054 & 40.3017 & 100 \\
12 & 46.1533 & 5.7362 & 0.1726 & 5.0711 & 2.0086 & 2.4527 & 38.4056 & 100 \\
16 & 44.2273 & 6.0016 & 0.2299 & 7.0307 & 2.8315 & 2.8059 & 36.8731 & 100 \\
20 & 43.2841 & 6.0203 & 0.3039 & 8.1073 & 3.2790 & 2.9059 & 36.0994 & 100 \\
24 & 42.9270 & 5.9611 & 0.3868 & 8.5218 & 3.4332 & 2.9014 & 35.8685 & 100 \\
\hline
\end{tabular}

\begin{tabular}{ccccccccc}
\multicolumn{8}{c}{ Fishing } \\
\hline Horizon & fsh & ibr & mss & mpr & exr & cpi & Y $_{j}$ & Total \\
\hline 1 & 74.0601 & 2.0723 & 0.7110 & 0.1211 & 0.1170 & 0.0024 & 22.9159 & 100 \\
4 & 62.0284 & 4.0040 & 0.5343 & 2.1078 & 0.4744 & 0.1007 & 30.7504 & 100 \\
8 & 55.1634 & 5.8806 & 0.5065 & 6.2497 & 1.3604 & 0.2224 & 30.6169 & 100 \\
12 & 51.7076 & 6.8043 & 0.5373 & 10.4406 & 2.3497 & 0.2400 & 27.9206 & 100 \\
16 & 49.3851 & 7.1708 & 0.5695 & 13.7161 & 3.1528 & 0.2226 & 25.7832 & 100 \\
20 & 47.7650 & 7.2642 & 0.5892 & 15.8374 & 3.6810 & 0.2317 & 24.6317 & 100 \\
24 & 46.7182 & 7.2456 & 0.5970 & 16.9953 & 3.9712 & 0.2813 & 24.1913 & 100 \\
\hline
\end{tabular}

\begin{tabular}{ccccccccc}
\multicolumn{8}{c}{ Livestock } \\
\hline Horizon & lvs & ibr & mss & mpr & exr & cpi & Y $_{\mathrm{j}}$ & Total \\
\hline 1 & 57.9037 & 2.9616 & 0.3704 & 0.0006 & 0.0180 & 0.0402 & 38.7055 & 100 \\
4 & 48.7505 & 4.7336 & 0.1158 & 0.5716 & 0.5077 & 0.3386 & 44.9823 & 100 \\
8 & 43.7230 & 6.4050 & 0.1290 & 2.6910 & 1.7638 & 0.8760 & 44.4122 & 100 \\
12 & 40.8607 & 7.2239 & 0.1577 & 5.2612 & 3.1290 & 1.2934 & 42.0741 & 100 \\
16 & 39.1345 & 7.4947 & 0.1858 & 7.2566 & 4.1299 & 1.4951 & 40.3034 & 100 \\
20 & 38.2563 & 7.5048 & 0.2149 & 8.3873 & 4.6580 & 1.5479 & 39.4309 & 100 \\
24 & 37.9066 & 7.4390 & 0.2461 & 8.8593 & 4.8472 & 1.5426 & 39.1591 & 100 \\
\hline
\end{tabular}

In what follows, we consider the influence of monetary policy shocks on agriculture at sub-sectoral level. Let us begin with the crop production sub-sector. The generalized impulse responses of the crop production sub-sector to monetary tightening as shown in Figure 2 indicates that the subsector responded immediately and negatively to innovation in money supply and monetary policy rate as theoretically expected. The highest negative response was attained after a lag of 2 and 6 quarters, respectively. In fact, the sub-sector persistently responded negatively all through, just like the aggregate agricultural sector. The response to interbank call rate declined after 2 quarters, became negative after 3 quarters and persistently remained negative afterwards. Clearly, these patterns are qualitatively similar to those of the aggregate agricultural sector. Indeed, the patterns of generalized impulse responses for the sub-sample as well as those of forestry, fishing and livestock are similar to the ones reported here for crop production in the full sample (to conserve space, we do not report the graphs for these other sub-sectors). In sum, our results indicate that even at subsectoral level, the agricultural sector consistently responded negatively to unanticipated monetary policy shock in most of the forecast horizon, in line with economic theory.

The NGFEVD of crop production in Table 1 indicates that apart from idiosyncratic conditions, the variables which significantly explain output variability in this sub-sector in the short-run are interbank call rate $(2.8 \%)$ and productive activities in other sectors of the economy (36.9\%). This implies that monetary policy affects the crop production subsector in the short-run through the interest rate and money demand (credit) channels. This is consistent with our earlier findings for the agricultural sector as a whole. However, in the long-run and in addition to these two channels, the roles of monetary policy rate $(8.6 \%)$ and exchange rate $(5.3 \%)$ become non-negligible. These findings are robust to the sub-sample estimation results in Table 7, the only difference being that the role of exchange rate remained unimportant both in the short-run and long-run. Overall, we find that the interest rate and credit channel are the main avenues through which the immediate impact of monetary policy shocks are transmitted to the crop production sub-sector. Is this finding applicable to forestry, fishing and livestock sub-sectors? Let us see.

The NGFEVD of forestry sub-sector in Table 1 is qualitatively the same as that of crop production. We find that apart from own innovations, the variables which significantly explain output variability in the forestry sub-sector in the short-run are interbank call rate (2.8\%) and productive activities in other sectors of the economy (37.4\%). In addition to these channels, we find that the roles of monetary policy rate $(8.5 \%)$ and exchange rate (3.4\%) are also important in the long-run. This means that the immediate effect of monetary policy is felt in the forestry subsector through the interest rate and money demand channels. As before, these results are qualitatively consistent with the subsample estimation results in Table 7, the only difference being that the role of exchange rate remained unimportant both in the short-run and long-run. In fact, these findings are consistent with those of fishing and livestock sub-sectors, both in the full sample and the sub-sample. This means that in Nigeria, the money supply channel plays a negligible role in the propagation of monetary policy shocks to the agricultural sector. 
At this point, we summarize our main findings as follows: (i) the agricultural sector responded negatively to unanticipated monetary policy shock in most of the forecast horizon in line with economic theory; (ii) the immediate impact of monetary policy shocks is transmitted to the agricultural sector through the interest rate and money demand channels; (iii) in addition to these channels, the roles of monetary policy rate and exchange rate are non-negligible in the long-run; and (iv) the money supply channel plays a negligible role in spreading monetary policy shocks to the agricultural sector in Nigeria.

Recall that we used the consumer price index to capture the general price level in this study. The estimation results in Table 1 indicate that in the short-run, the money supply channel is the main avenue through which monetary policy shocks are transmitted to the general price level. However, in the long-run, both money supply (6.2\%) and monetary policy rate $(2.6 \%)$ become important. The roles of interbank call rate and exchange rate remained negligible all through. However, in the sub-sample period, we find that apart from own shocks, exchange rate (11.4\%) and interbank call rate (2.3\%) were dominant in the short-run; but in the long-run, money supply (38.7\%), economic activities in the aggregate economy (5.1\%) and exchange rate (2.9\%) play important roles in accounting for the variations in the general price level. These findings are consistent with the dynamics of the Nigerian economy in which deterioration in the nominal naira to U.S. dollar exchange rate usually affects the general price level swiftly while overall economic activities in the economy and money supply dynamics reflect in the general price level more gradually.

\section{CONCLUSION}

This study provides a pioneer disaggregated analysis of the effects of monetary policy shocks on the agricultural sector in Nigeria. The study utilized the generalized impulse responses and the normalized generalized forecast error variance decompositions from an underlying VAR model, which are order-invariant. The four monetary policy variables used in the study are interbank call rate, monetary policy rate, broad money supply and exchange rate; while the four agricultural sub-sectors investigated are crop production, forestry, fishing and livestock. The study also controlled for the general price level and other economic activities in the overall economy. The findings indicate that the aggregate agricultural sector and its various sub-sectors consistently responded negatively to unanticipated monetary tightening in most of the forecast horizon; and that the immediate impact of monetary policy shocks is transmitted to the agricultural sector through the interest rate and money demand channels. The findings further indicate that apart from these two channels, the roles of monetary policy rate and exchange rate are non-negligible in the long-run; while the role of money supply channel in spreading monetary policy shocks to the agricultural sector remained muted all through.

In terms of policy, the findings of this study support the creation of more credit schemes like the Agricultural Credit
Guarantee Scheme Fund so that farmers can access credits at single digit interest rate. Given the significant roles of interest rate and credit channels in the short-run, this study further recommends that the $\mathrm{CBN}$ should evolve ways of reducing interest rate for credits to the agricultural sector and increasing credits to the real sectors (such as the agricultural sector) of the economy. In other words, the CBN should seek out ways of reversing the current apathy by deposit money banks towards lending to the productive sectors of the economy, especially the agricultural sector. In the long term, this study urges the CBN to evolve credit and exchange rate policies that will promote the development of the agricultural sector and the overall real sector of the Nigerian economy.

\section{REFERENCES}

Alam, T. and Waheed, M. (2006), "Sectoral Effects of Monetary Policy: Evidence from Pakistan," The Pakistan Development Review, 45(4), 1103 - 1115.

Anthony-Orji, O. I, Orji, A, Ogbuabor, J. E. \& Ezealigo P. (2020). "Empirical analysis of agricultural and nonagricultural exports' impact on infrastructural investment in Nigeria”.. Ekonomika APK, 2020 (5), pp. 87 - 96 [English]. https://doi.org/10.32317/2221-1055.202005087

Bernanke, B. and Gertler, M. (1995), "Inside the Black Box: The Credit Channel of Monetary Transmission," Journal of Economic Perspectives, 9(4), 27-48. http://dx.doi.org/10.1257/ jep.9.4.27.

CBN (2014), "Effects of Monetary Policy on the Real Economy of Nigeria: A Disaggregated Analysis," Occasional Paper 54, Real Sector Division, Research Department, CBN.

Cooley, T. F. and Leroy, S. F. (1985), "Atheoretical Macroeconometrics: A Critique," Journal of Monetary Economics, 16(3), 283-308.

Crawford, C. (2007), "The Sectoral Impact of Monetary Policy in Australia: A structural VAR Approach," Thesis, University of Sydney. Retrieved 09 July 2018 from: https:// ses.library.usyd.edu.au/handle/2123/2293.

Darby, J. and Phillips, H. (2007), "Exploring the Implications of UK Monetary Policy for

Sectors of the UK and Scottish Economies," Centre for Public Policy for Regions, Discussion Paper No. 16.

Diebold, F. X. and Yilmaz, K. (2014), "On the Network Topology of Variance Decompositions:

Measuring the Connectedness of Financial Firms," Journal of Econometrics, 182(1), 119-134.

Ganley J. and Salmon, C. (1997), "The Industrial Impact of Monetary Policy Shocks: Some stylized facts," Bank of England Working Paper No. 68, Bank of England, London. 
Jansen, D. W., Kishan, R. P. and Vacaflores, D. E. (2013), "Sectoral Effects of Monetary Policy: The Evidence from Publicly Traded Firms," Southern Economic Journal, 79(4), $946-970$.

Koop, G., Pesaran, M. H. and Potter, S. M. (1996), "Impulse Response Analysis in Nonlinear Multivariate Models," Journal of Econometrics, 74, 119 - 147.

Lawson, J. and Rees, D. (2008), "A Sectoral Model of the Australian Economy," Reserve Bank of Australia, Research Discussion Paper 2008-01.

Llaudes, R. (2007), "Monetary Policy Shocks in a Two-sector Open Economy: An Empirical Study," European Central Bank (ECB) Working Paper No. 799. Retrieved 09 July 2018 from: https://papers.ssrn.com/sol3/papers.cfm?abstract_id=1005119.

Mishkin, F. S. (2007), "Housing and the Monetary Transmission Mechanism”, NBER Working Paper No 13518.

Moussir, C. E. and Chatri, A. (2017), "Sectoral Effects of Monetary Policy: Evidence from Morocco", Finance et Finance Internationale, Institut Marocain de l'Information Scientifique et Technique, https://hal.archives-ouvertes.fr/ hal-01449475.

Nampewo, D., Munyambonera, E. and Lwanga, M. (2013), "Sectoral Effects of Monetary Policy in Uganda," Journal of Empirical Economics, 1(2), 43 - 58.

National Bureau of Statistics (2016), "Nigerian Gross Domestic Product Report”, Issue 09, Quarter One, 2016, National Bureau of Statistics, Abuja.

Nwosa, P. I. and Saibu, M. O. (2012), “The Monetary Transmission Mechanism in Nigeria: A Sectoral Output Analysis," International Journal of Economics and Finance, 4(1), $204-212$.

Ogbuabor, J. E., Eigbiremolen, G. O., Aneke, G. C. and Manasseh, C. O. (2018), "Measuring the

Dynamics of APEC Output Connectedness," Asian-Pacific Economic Literature, 32(1), doi: 10.1111/apel.12218.

Ogbuabor, J. E. and Nwosu, C. A. (2017), “The Impact of Deposit Money Bank's Agricultural Credit on Agricultural Productivity in Nigeria: Evidence from an Error Correction Model," International Journal of Economics and Financial Issues, 7(2), 513 - 517.

Ogbuabor, J. E., Orji, A., Aneke, G. C. and Erdene-Urnukh, O. (2016), "Measuring the Real and

Financial Connectedness of Selected African Economies with the Global Economy," South African Journal of Economics, 84(3), 364 - 399, doi: 10.1111/saje.12135.
Oluwaseyi, A. B. (2017), "The Prospects of Agriculture in Nigeria: How our Fathers Lost their Way - A Review," Asian Journal of Economics, Business and Accounting, 4(2), 1 - 30.

Orji, A., Ogbuabor, J. E, Anthony-Orji, O.I and Alisigwe, J. N (2020). "Agricultural Financing and Agricultural Output Growth in Developing Economies: Any Causal Linkage in Nigeria? International Journal of Finance, Insurance and Risk Management, 10 (2), 34-43, 2020. DOI: 10.35808/ijfirm/213. Available online: https://www.journalfirm.com/journal/213\#

Orji, A, Ogbuabor, J.E, Okeke C. M and Anthony-Orji O.I (2019). "Exchange Rate Movements and the Agricultural Sector in Nigeria: An Empirical Investigation" Journal of Academic Research in Economics 11 (3), 616-627. Available online: http://www.jare-sh.com/downloads/dec_2019/orji1.pdf

Orji, A.,Ogbuabor, J.E and Umesiobi, S (2014), "Agricultural Outputs, Food Security and Economic Development: Some Policy Options and Strategies for Africa" European Journal of Social Sciences 45(3):305-318. Available at: http://www. europeanjournalofsocialsciences.com/issues/EJSS_45_3.html

Otero, J. D. Q. (2017), “Industrial structure and transmission of monetary policy in Latin American countries," Investigación Económica, LXXVI(302), 103-129.

Pellényi, G. (2012), “The sectoral effects of monetary policy in Hungary: A structural factor

Analysis," Magyar Nemzeti Bank (MNB), Working Papers No. 2012/1. Retrieved 09 July 2018 from: https://www.mnb. hu/letoltes/wp-2012-01.pdf.

Pesaran, M. H. and Shin, Y. (1998), “Generalized Impulse Response Analysis in Linear Multivariate Models," Economics Letters, 58, 17-29.

Raddatz, C. and Rigobon, R. (2003), "Monetary Policy and Sectoral Shocks: Did the Fed React properly to the High-Tech Crisis?" National Bureau of Economic Research (NBER) Working Paper No. 9835.

Sengupta, N (2014), "Sectoral Effects of Monetary Policy in India," South Asian Journal of Macroeconomics and Public Finance, 3(1), 127 - 154.

Sims, C. A. (1980), "Macroeconomics and Reality," Econometrica, 48(1), 1 - 48.

Singh, S. K. and Rao, D. T. (2014), "Sectoral effects of monetary policy shock: Evidence from India," Munich Personal RePEc Archive (MPRA) Paper No. 62069. Retrieved 09 July 2018 from: http://mpra.ub.uni-muenchen.de/62069/. 


\section{Appendix}

Table 2: Descriptive Statistics of the Variables

\begin{tabular}{lcccccccccc}
\hline & AGR & CPR & FRS & FSH & LVS & CPI & EXR & IBR & MPR & MSS \\
\hline Mean & $5,000.18$ & $4,328.05$ & 77.84 & 109.25 & 485.05 & 59.97 & 76.59 & 12.78 & 12.97 & $4,259.41$ \\
Maximum & $12,586.76$ & $11,273.55$ & 131.00 & 240.79 & 941.42 & 211.52 & 305.21 & 32.52 & 26.91 & $23,388.33$ \\
Minimum & $2,259.79$ & $1,711.50$ & 30.16 & 39.19 & 216.10 & 0.15 & 0.55 & 1.61 & 4.81 & 12.85 \\
Std. Dev. & $2,850.94$ & $2,638.63$ & 23.41 & 51.01 & 172.05 & 50.95 & 71.81 & 5.67 & 4.20 & $6,417.50$ \\
\hline
\end{tabular}

Note: The statistics were computed using the raw data before they were logged for estimation.

Table 3: Unit Root Test Results

ADF Tests

Phillips-Perron Tests

\begin{tabular}{lcccc|cccccc}
\hline & Level & $\begin{array}{c}5 \% \text { Critical } \\
\text { Value }\end{array}$ & 1st Diff & $\begin{array}{c}5 \% \text { Critical } \\
\text { Value }\end{array}$ & $\begin{array}{c}\text { Order of } \\
\text { Integration }\end{array}$ & Level & $\begin{array}{c}5 \% \text { Critical } \\
\text { Value }\end{array}$ & $\begin{array}{c}\text { 1st Diff } \\
\text { Is }\end{array}$ & $\begin{array}{c}5 \% \text { Critical } \\
\text { Value }\end{array}$ & $\begin{array}{c}\text { Order of } \\
\text { Integration }\end{array}$ \\
\hline AGR & -1.9778 & -3.4425 & -5.1642 & -3.4425 & $\mathrm{I}(1)$ & -2.3361 & -3.4416 & -12.6240 & -3.4418 & $\mathrm{I}(1)$ \\
CPR & -1.9650 & -3.4425 & -5.1216 & -3.4425 & $\mathrm{I}(1)$ & -2.3743 & -3.4416 & -12.6483 & -3.4418 & $\mathrm{I}(1)$ \\
FRS & -2.5369 & -3.4416 & -14.6334 & -3.4418 & $\mathrm{I}(1)$ & -2.4554 & -3.4416 & -14.5544 & -3.4418 & $\mathrm{I}(1)$ \\
FSH & -1.8598 & -3.4416 & -10.5119 & -3.4418 & $\mathrm{I}(1)$ & -2.1099 & -3.4416 & -10.5004 & -3.4418 & $\mathrm{I}(1)$ \\
LVS & -2.1716 & -3.4416 & -11.3749 & -3.4418 & $\mathrm{I}(1)$ & -2.1594 & -3.4416 & -11.3860 & -3.4418 & $\mathrm{I}(1)$ \\
CPI & -4.4603 & -3.4416 & - & - & $\mathrm{I}(0)$ & -4.4603 & -3.4416 & - & - & $\mathrm{I}(0)$ \\
IBR & -4.7713 & -3.4416 & - & - & $\mathrm{I}(0)$ & -4.6158 & -3.4416 & - & - & $\mathrm{I}(0)$ \\
MPR & -2.4442 & -3.4427 & -5.4347 & -3.4427 & $\mathrm{I}(1)$ & -3.1088 & -3.4416 & -6.9898 & -3.4418 & $\mathrm{I}(1)$ \\
EXR & -1.3771 & -3.4416 & -10.4272 & -3.4418 & $\mathrm{I}(1)$ & -1.3771 & -3.4416 & -10.4067 & -3.4418 & $\mathrm{I}(1)$ \\
MSS & -1.2515 & -3.4416 & -12.5707 & -3.4418 & $\mathrm{I}(1)$ & -1.4813 & -3.4416 & -12.5741 & -3.4418 & $\mathrm{I}(1)$ \\
\hline
\end{tabular}

Table 4: Johansen Cointegration Test Results

\begin{tabular}{|c|c|c|c|c|c|c|}
\hline Hypothesized No. of CE(s) & Trace Statistic & $5 \%$ Critical Value & Prob & $\begin{array}{c}\text { Max-Eigen } \\
\text { Statistic }\end{array}$ & $5 \%$ Critical Value & Prob \\
\hline None $*$ & 226.5263 & 150.5585 & 0.0000 & 57.4311 & 50.5999 & 0.0085 \\
\hline At most $1 *$ & 169.0951 & 117.7082 & 0.0000 & 48.3810 & 44.4972 & 0.0180 \\
\hline At most $2 *$ & 120.7142 & 88.8038 & 0.0000 & 47.3712 & 38.3310 & 0.0036 \\
\hline At most $3 *$ & 73.3430 & 63.8761 & 0.0065 & 32.7848 & 32.1183 & 0.0414 \\
\hline At most 4 & 40.5581 & 42.9153 & 0.0844 & 21.5698 & 25.8232 & 0.1652 \\
\hline At most 5 & 18.9883 & 25.8721 & 0.2815 & 12.8174 & 19.3870 & 0.3430 \\
\hline At most 6 & 6.1710 & 12.5180 & 0.4389 & 6.1710 & 12.5180 & 0.4389 \\
\hline
\end{tabular}

Table 5: VAR Lag Order Selection for the Full Sample Six-variable Agricultural Output Model

\begin{tabular}{lcccccc} 
Lag & LogL & LR & FPE & AIC & SC & HQ \\
\hline 0 & -639.6950 & NA & 0.000536 & 9.495515 & 9.624014 & -547734 \\
1 & 367.5036 & 1910.715 & $3.36 \mathrm{e}-10$ & -4.786818 & $-3.887322 *$ & $-4.421286^{*}$ \\
2 & 405.5081 & 68.74335 & $3.27 \mathrm{e}-10$ & -4.816295 & -3.145802 & -4.137449 \\
3 & 452.7151 & 81.22379 & $2.80 \mathrm{e}-10$ & -4.981104 & -2.539614 & -3.988944 \\
4 & 480.7371 & 45.74181 & $3.19 \mathrm{e}-10$ & -4.863781 & -1.651294 & -3.558308 \\
5 & 535.4324 & $84.45600^{*}$ & $2.48 \mathrm{e}-10 *$ & $-5.138712 *$ & -1.155228 & -3.519925 \\
6 & 563.7041 & 41.16029 & $2.88 \mathrm{e}-10$ & -5.025060 & -0.270580 & -3.092960 \\
7 & 581.0798 & 23.76386 & $3.98 \mathrm{e}-10$ & -4.751174 & 0.774304 & -2.505760 \\
8 & 596.8724 & 20.20518 & $5.74 \mathrm{e}-10$ & -4.454006 & 1.842469 & -1.895278 \\
\hline
\end{tabular}

* indicates lag order selected by the criterion

LR: sequential modified LR test statistic (each test at 5\% level)

FPE: Final prediction error

AIC: Akaike information criterion

SC: Schwarz information criterion

HQ: Hannan-Quinn information criterion 
Table 6: VAR Stability Test for the Full Sample Six-variable Agricultural Output Model

\begin{tabular}{ll}
\hline Root & Modulus \\
0.993457 & 0.993457 \\
0.950850 & 0.950850 \\
$0.847095-0.101039 \mathrm{i}$ & 0.853100 \\
$0.847095+0.101039 \mathrm{i}$ & 0.853100 \\
0.730511 & 0.730511 \\
$0.204351-0.384338 \mathrm{i}$ & 0.435287 \\
$0.204351+0.384338 \mathrm{i}$ & 0.435287 \\
$0.266467-0.205951 \mathrm{i}$ & 0.336780 \\
$0.266467+0.205951 \mathrm{i}$ & 0.336780 \\
$0.087763-0.055252 \mathrm{i}$ & 0.103707 \\
$0.087763+0.055252 \mathrm{i}$ & 0.103707 \\
-0.073422 & 0.073422 \\
\hline
\end{tabular}

No root lies outside the unit circle.

VAR satisfies the stability condition.

Table 7: Sub-Sample NGFEVD (1994Q1 - 2016Q4)

Agricultural Output

\begin{tabular}{|c|c|c|c|c|c|c|c|c|}
\hline Horizon & agr & ibr & mss & & mpr & exr & cpi & Total \\
\hline 1 & 92.9894 & 6.0370 & 0.0017 & & 0.9692 & 0.0024 & 0.0002 & 100 \\
\hline 4 & 89.2671 & 10.0432 & 0.0241 & & 0.5280 & 0.1255 & 0.0120 & 100 \\
\hline 8 & 85.9407 & 11.3460 & 0.0274 & & 2.4581 & 0.1912 & 0.0366 & 100 \\
\hline 12 & 83.0270 & 11.3894 & 0.0264 & & 5.3056 & 0.2047 & 0.0469 & 100 \\
\hline 16 & 81.4721 & 11.1004 & 0.0261 & & 7.1546 & 0.2004 & 0.0465 & 100 \\
\hline 20 & 81.0420 & 10.8934 & 0.0255 & & 7.7915 & 0.1973 & 0.0502 & 100 \\
\hline 24 & 81.0392 & 10.8160 & 0.0271 & & 7.8572 & 0.1983 & 0.0623 & 100 \\
\hline \multicolumn{9}{|c|}{ Consumer Price Index } \\
\hline Horizon & agr & ibr & mss & & mpr & exr & cpi & Total \\
\hline 1 & 0.0002 & 2.3094 & 0.8297 & & 0.5905 & 11.3887 & 84.8814 & 100 \\
\hline 4 & 0.1649 & 3.1243 & 6.7486 & & 2.1044 & 9.0375 & 78.8204 & 100 \\
\hline 8 & 0.1901 & 2.8929 & 16.5931 & & 2.9091 & 6.5577 & 70.8571 & 100 \\
\hline 12 & 0.2329 & 2.4786 & 25.3264 & & 2.6836 & 5.0250 & 64.2535 & 100 \\
\hline 16 & 0.9932 & 2.0498 & 31.8486 & & 2.2134 & 4.0486 & 58.8463 & 100 \\
\hline 20 & 2.7479 & 1.6953 & 36.1536 & & 1.8272 & 3.3744 & 54.2016 & 100 \\
\hline 24 & 5.1472 & 1.4517 & 38.7388 & & 1.5548 & 2.8841 & 50.2234 & 100 \\
\hline \multicolumn{9}{|c|}{ Crop Production } \\
\hline Horizon & $\mathrm{cpr}$ & $\mathrm{ibr}$ & mss & $\mathrm{mpr}$ & exr & cpi & $Y_{j}$ & Total \\
\hline 1 & 58.0404 & 3.6653 & 0.0011 & 0.6014 & 0.0002 & 0.0011 & 37.6905 & 100 \\
\hline 4 & 55.3527 & 6.2651 & 0.0140 & 0.3449 & 0.0737 & 0.0152 & 37.9345 & 100 \\
\hline 8 & 53.8814 & 7.0558 & 0.0133 & 1.6225 & 0.1106 & 0.0405 & 37.2760 & 100 \\
\hline 12 & 52.6966 & 7.2057 & 0.0131 & 3.5114 & 0.1358 & 0.0516 & 36.3859 & 100 \\
\hline 16 & 51.9911 & 7.0706 & 0.0131 & 4.6970 & 0.1417 & 0.0514 & 36.0351 & 100 \\
\hline 20 & 51.7639 & 6.9306 & 0.0140 & 5.0239 & 0.1388 & 0.0535 & 36.0754 & 100 \\
\hline 24 & 51.7390 & 6.8722 & 0.0169 & 4.9976 & 0.1366 & 0.0619 & 36.1758 & 100 \\
\hline
\end{tabular}


Forestry

\begin{tabular}{|c|c|c|c|c|c|c|c|c|}
\hline Horizon & frs & $\mathrm{ibr}$ & mss & $\mathrm{mpr}$ & exr & cpi & $Y_{j}$ & Total \\
\hline 1 & 55.6859 & 2.9441 & 0.7445 & 0.9213 & 0.8010 & 0.2955 & 38.6078 & 100 \\
\hline 4 & 49.9118 & 3.7941 & 0.4773 & 0.4904 & 0.5879 & 0.2517 & 44.4867 & 100 \\
\hline 8 & 47.1520 & 4.9723 & 0.3776 & 1.8436 & 0.4606 & 0.2417 & 44.9521 & 100 \\
\hline 12 & 45.8455 & 5.2271 & 0.3695 & 3.8776 & 0.4430 & 0.2601 & 43.9773 & 100 \\
\hline 16 & 45.1903 & 5.1253 & 0.3879 & 5.2335 & 0.4325 & 0.2915 & 43.3390 & 100 \\
\hline 20 & 44.9390 & 4.9927 & 0.4269 & 5.6659 & 0.4193 & 0.3359 & 43.2203 & 100 \\
\hline 24 & 44.8450 & 4.9221 & 0.4870 & 5.6570 & 0.4092 & 0.3916 & 43.2881 & 100 \\
\hline \multicolumn{9}{|c|}{ Fishing } \\
\hline Horizon & fsh & $\mathrm{ibr}$ & $\mathrm{mss}$ & $\mathrm{mpr}$ & exr & cpi & $\mathrm{Y}_{\mathrm{j}}$ & Total \\
\hline 1 & 65.3053 & 2.3214 & 1.2461 & 0.2425 & 1.2515 & 0.2428 & 29.3904 & 100 \\
\hline 4 & 48.3266 & 4.5832 & 0.7242 & 0.7963 & 0.6588 & 0.1397 & 44.7712 & 100 \\
\hline 8 & 43.4592 & 6.2173 & 0.5892 & 3.7927 & 0.4725 & 0.1071 & 45.3619 & 100 \\
\hline 12 & 41.3407 & 6.5150 & 0.5622 & 7.3376 & 0.4462 & 0.1022 & 43.6962 & 100 \\
\hline 16 & 40.4795 & 6.3359 & 0.5456 & 9.3806 & 0.4364 & 0.1071 & 42.7148 & 100 \\
\hline 20 & 40.3121 & 6.1398 & 0.5436 & 9.7715 & 0.4214 & 0.1259 & 42.6858 & 100 \\
\hline 24 & 40.3100 & 6.0599 & 0.5669 & 9.5543 & 0.4081 & 0.1590 & 42.9417 & 100 \\
\hline \multicolumn{9}{|c|}{ Livestock } \\
\hline Horizon & lvs & $\mathrm{ibr}$ & $\mathrm{mss}$ & $\mathrm{mpr}$ & exr & cpi & $Y_{j}$ & Total \\
\hline 1 & 55.8494 & 2.8343 & 0.9042 & 0.2737 & 0.6432 & 0.1223 & 39.3729 & 100 \\
\hline 4 & 47.3608 & 4.4612 & 0.3469 & 0.1857 & 0.2966 & 0.1039 & 47.2449 & 100 \\
\hline 8 & 44.0020 & 6.0907 & 0.2642 & 1.3576 & 0.2459 & 0.1013 & 47.9384 & 100 \\
\hline 12 & 42.7847 & 6.4438 & 0.2786 & 3.1232 & 0.2556 & 0.1187 & 46.9954 & 100 \\
\hline 16 & 42.2959 & 6.3266 & 0.3038 & 4.2429 & 0.2526 & 0.1525 & 46.4257 & 100 \\
\hline 20 & 42.1311 & 6.1812 & 0.3339 & 4.5481 & 0.2459 & 0.2010 & 46.3588 & 100 \\
\hline 24 & 42.0593 & 6.1152 & 0.3749 & 4.5177 & 0.2437 & 0.2573 & 46.4319 & 100 \\
\hline
\end{tabular}

